\title{
Costs of adverse events associated with erlotinib or afatinib in first-line treatment of advanced EGFR-positive non-small cell lung cancer
}

This article was published in the following Dove Press journal:

ClinicoEconomics and Outcomes Research

30 December 2016

Number of times this article has been viewed

\section{Dolores Isla' \\ Javier De Castro² \\ Oscar Juan ${ }^{3}$ \\ Santiago $\mathrm{Grau}^{4}$ \\ Javier Orofino ${ }^{5}$ \\ Rocío Gordo 5 \\ Carlos Rubio-Terrés ${ }^{6}$ \\ Darío Rubio-Rodríguez ${ }^{6}$}

'Medical Oncology Department, Clinical Universitary Hospital Lozano Blesa, Zaragoza, ${ }^{2}$ Medical Oncology Department, Universitary Hospital La Paz, Madrid, ${ }^{3}$ Medical Oncology Department, Universitary and Polytechnic Hospital La Fe, Valencia, ${ }^{4}$ Pharmacy Department, Del Mar Hospital, Barcelona, ${ }^{5}$ Roche Farma, S.A., Health Economics, ${ }^{6}$ Health Value, Health Economics, Madrid, Spain

Correspondence: Darío Rubio Rodríguez Health Value, C/Virgen de Aránzazu, 21, 28034 Madrid, Spain

Email drubiorodriguez@healthvalue.org
Objectives: Epidermal growth factor receptor-tyrosine kinase inhibitors (EGFR-TKIs) are an established treatment for advanced non-small cell lung cancer (NSCLC) with EGFR mutation. According to published meta-analyses, no significant efficacy differences have been demonstrated between erlotinib and afatinib. However, the incidence of EGFR-TKI-related adverse events (AEs) was lower with erlotinib. This study compares the cost of management of the AEs associated with these two drugs from the perspective of the Spanish National Health System (NHS). Methods: The frequency of AEs was established from a recently published meta-analysis. In Spain, the daily cost of both drugs can be considered similar; as a result, only the costs of management of the AEs were considered. Costs and resource utilization in the management of the AEs were estimated by a panel of Spanish oncologists and from studies previously carried out in Spain. A probabilistic analysis was performed based on a Monte Carlo simulation.

Results: The model generated 1,000 simulations. The total cost per patient treated with erlotinib and afatinib was $€ 657.44$ and $€ 1,272.15$, respectively. With erlotinib, the cost per patient and per $\mathrm{AE}$ of grades $\leq 2$ and $\geq 3$ was $€ 550.86$ and $€ 106.58$, respectively, whereas the cost with afatinib was $€ 980.63$ and $€ 291.52$, respectively. The reduction in the number of AEs with erlotinib could avoid a mean cost for the NHS of $€ 614.71$ (95\% CI: $€ 342.57-881.29)$ per patient. Conclusion: In advanced EGFR mutation-positive NSCLC patients, first-line treatment with erlotinib could reduce health care costs for the NHS, due to a decrease in the AE rate compared with afatinib. In long-term treatments, the avoidance of complications and the lowering of costs associated with the management of AEs are relevant factors that contribute to the sustainability of the health system.

Keywords: adverse event, afatinib, cost analysis, erlotinib, non-small cell lung cancer

\section{Introduction}

Lung cancer is the leading cause of cancer death in Spain, with 21,645 deaths in 2013. ${ }^{1}$ Approximately, 27,000 new cases are diagnosed each year, ${ }^{2}$ most of them in locally advanced or metastatic stages of the disease (IIIB and IV). ${ }^{3}$ Non-small cell lung cancer (NSCLC) is the most common histological subtype, accounting for $80 \%-85 \%$ of all lung cancers. ${ }^{3-5}$ It has been shown that $7 \%-17 \%$ of NSCLCs harbor a type 1 epidermal growth factor receptor (EGFR)-activating mutation in non-Asian populations. ${ }^{6,7}$

Erlotinib, gefitinib, and afatinib are EGFR-tyrosine kinase inhibitors (EGFR-TKIs) indicated for the first-line treatment of patients with locally advanced or metastatic NSCLC harboring EGFR-activating mutations. ${ }^{8-10}$ Erlotinib and gefitinib are EGFR-TKIs that reversibly inhibit EGFR. ${ }^{11,12}$ Afatinib is an irreversible EGFR-TKI that inhibits various ERBB receptor family members (including EGFR, HER2, ERBB3, and ERBB4). ${ }^{13}$ 
The efficacy and safety of EGFR-TKIs have been analyzed in several meta-analyses. ${ }^{14-18}$ The most recently published network meta-analyses indicate a high efficacyhigh toxicity profile for afatinib, a high efficacy-moderate toxicity profile for erlotinib, and a medium efficacy-moderate toxicity profile for gefitinib. ${ }^{18}$ Therefore, based on these results, afatinib and erlotinib might be superior choices for chemo-naïve EGFR mutant patients in terms of efficacy, although with differences in toxicity profile between them. ${ }^{18}$ Regarding direct comparisons, there have not been carried out head-to-head trials comparing erlotinib and afatinib in EGFR mutant patients. The first exploratory prospective head-to-head comparison in this setting is the LUX-Lung 7 phase IIb study that indicates that afatinib might offer improved efficacy compared with gefitinib in its primary endpoints, without new safety signals. ${ }^{19}$ On the other hand, the CTONG0901 trial showed that erlotinib produced numerically longer PFS and overall survival than gefitinib in patients with "EGFR" mutations but without statistically significant differences. ${ }^{20}$

Considering that there are no differences in terms of efficacy between erlotinib and afatinib and in the absence of head-to-head comparison, we decided to assess the hypothesis that erlotinib might involve fewer costs associated with the management of adverse events (AEs) than afatinib.

This study compares the cost of management of the AEs associated with these two drugs in the first-line treatment of patients with locally advanced or metastatic NSCLC with EGFR mutation, from the perspective of the Spanish National Health System (NHS).

\section{Methods}

\section{Economic model}

The study comprised an economic model defined as a theoretical construct allowing the simulation of complex health care processes related to drugs and developed following a previously established protocol based on estimates obtained from the available data. The model, which was generated using Microsoft Excel, simulated the evolution of a hypothetical cohort of patients treated with erlotinib or afatinib and calculated the cost per patient of managing the AEs associated with either treatment, as observed in the clinical trials, which were evaluated in the direct and indirect comparisons meta-analysis published by Haaland et al. ${ }^{14}$ The model was generated from the perspective of the NHS; accordingly, it only included direct health care costs, with a time horizon equivalent to the duration of follow-up of the patients in the clinical trials included in the meta-analysis. ${ }^{21-24}$

\section{Target population}

The target population comprised the hypothetical total patients in which the theoretical analysis was carried out, and thus the population to which the study results may be applied. These patients were individuals presenting locally advanced or metastatic NSCLC and EGFR mutations.

\section{AEs}

Five meta-analyses of clinical trials comparing the toxicity of erlotinib and afatinib were identified. ${ }^{14-18}$ The only metaanalysis considering the overall AEs observed in the clinical trials was that of Haaland et al. ${ }^{14}$ As a result, this was the meta-analysis used in the economic model as the source of frequencies of the AEs reported for both EGFR-TKIs. The eligible patient population included in this meta-analysis has the same clinical characteristics as the target population in the economic analysis. This was a direct and indirect comparison meta-analysis performed using mixed-effects log-linear models. It included two randomized phase III trials with erlotinib (EURTAC and OPTIMAL trials). In the first study as the pivotal trial, erlotinib was compared with gemcitabine plus carboplatin, ${ }^{21,22}$ whereas the second study compared erlotinib versus cisplatin plus docetaxel or gemcitabine (carboplatin was allowed in patients unable to have cisplatin). ${ }^{25}$ The analysis also included the two randomized phase III pivotal trials with afatinib (LUX-Lung 3 and LUX-Lung 6 trials). The first compared afatinib versus pemetrexed plus cisplatin, ${ }^{23}$ whereas the second study compared afatinib versus gemcitabine plus cisplatin. ${ }^{24,26}$ The results of the meta-analysis in relation to the AEs observed with erlotinib and afatinib are shown in Table 1. To understand how AE rates shown in Table 1 were obtained from the meta-analysis of Haaland et al, ${ }^{14}$ an example is presented below. According to the meta-analysis of Haaland et al ${ }^{14}$ the anemia grade $\geq 3$ average rate for erlotinib is $1 \%$ (Table 1). As the total rate of anemia with erlotinib is $8 \%$ (Haaland et al), ${ }^{14}$ it follows that the average rate of grade $\leq 2$ anemia is the difference ( $7 \%$; Table 2 ).

The results of LUX-Lung 3 and LUX-Lung 6 trials have been very recently published in the US "National Institutes of Health" ClinTrials database. ${ }^{27,28}$ The AE rates described in the database differ slightly from those previously published. ${ }^{23,26}$ Consequently, a sub-analysis was made, considering the values available in ClinTrials ${ }^{27,28}$ (Table 2).

\section{Cost estimates}

In Spain, the daily cost of treatment with erlotinib and afatinib at the doses recommended in the respective Summaries of Product Characteristics (150 and $40 \mathrm{mg} /$ day, respectively $)^{8,10}$ 
Table I Frequency of adverse events with erlotinib and afatinib

\begin{tabular}{|c|c|c|c|c|c|c|c|c|c|}
\hline \multirow[t]{2}{*}{ Adverse events } & \multicolumn{3}{|l|}{ Erlotinib } & \multicolumn{3}{|c|}{ Afatinib (Haaland et al) ${ }^{14}$} & \multicolumn{3}{|c|}{ Afatinib (clinical trials) ${ }^{27,28}$} \\
\hline & $\begin{array}{l}\text { Average } \\
(\%)\end{array}$ & $\begin{array}{l}\text { LL 95\% } \\
\mathrm{Cl}(\%)\end{array}$ & $\begin{array}{l}\text { UL 95\% } \\
\mathrm{Cl}(\%)\end{array}$ & $\begin{array}{l}\text { Average } \\
\text { (\%) }\end{array}$ & $\begin{array}{l}\text { LL 95\% } \\
\text { CI (\%) }\end{array}$ & $\begin{array}{l}\text { UL 95\% } \\
\text { CI (\%) }\end{array}$ & $\begin{array}{l}\text { Average } \\
\text { (\%) }\end{array}$ & $\begin{array}{l}\text { LL 95\% } \\
\mathrm{Cl}(\%)\end{array}$ & $\begin{array}{l}\text { UL 95\% } \\
\text { Cl (\%) }\end{array}$ \\
\hline \multicolumn{10}{|c|}{ Adverse events grade $<2$} \\
\hline Anemia & 7.0 & 4.0 & 11.0 & 3.0 & 1.0 & 4.0 & 7.0 & 6.1 & 7.0 \\
\hline Asthenia (fatigue) & 20.0 & 3.0 & 59.0 & 16.0 & 13.0 & 19.0 & 21.4 & 19.7 & 23.1 \\
\hline Anorexia & 31.0 & 22.0 & 37.0 & 18.0 & 15.0 & 20.0 & 21.5 & 15.1 & 27.9 \\
\hline Arthralgia & 10.0 & 6.0 & 17.0 & 0.0 & 0.0 & 0.0 & 3.5 & 0.0 & 7.0 \\
\hline Diarrhea & 37.0 & 20.0 & 57.0 & 86.0 & 88.0 & 79.0 & 89.3 & 89.1 & 89.5 \\
\hline Rash & 71.0 & 63.0 & 68.0 & 74.0 & 72.0 & 73.0 & 67.8 & 62.9 & 72.8 \\
\hline Stomatitis/mucositis & 12.0 & 8.0 & 15.0 & 65.0 & 61.0 & 67.0 & 29.7 & 21.8 & 37.6 \\
\hline Constipation & 0.0 & 0.0 & 0.0 & 3.0 & 1.0 & 4.0 & 8.4 & 3.8 & 13.1 \\
\hline Infection & 16.0 & 1.0 & 19.0 & 0.0 & 0.0 & 0.0 & 28.5 & 15.1 & 41.9 \\
\hline Leukopenia & 0.0 & 0.0 & 0.0 & 2.0 & 1.0 & 2.0 & 4.7 & 2.6 & 6.7 \\
\hline Nausea & 0.0 & 0.0 & 0.0 & 17.0 & 13.0 & 20.0 & 18.5 & 11.7 & 25.3 \\
\hline Neurotoxicity & 9.0 & 5.0 & 12.0 & 0.0 & 0.0 & 0.0 & 0.0 & 0.0 & 0.0 \\
\hline Neutropenia & 1.0 & 0.0 & 13.0 & 1.0 & 0.0 & 1.0 & 3.4 & 1.3 & 5.4 \\
\hline Pruritus & 0.0 & 0.0 & 0.0 & 19.0 & 14.0 & 22.0 & 15.7 & 11.3 & 20.1 \\
\hline \multicolumn{9}{|l|}{ inflammation) } & 24.3 \\
\hline Thrombocytopenia & 2.0 & 1.0 & 4.0 & 0.0 & 0.0 & 0.0 & 1.3 & 0.0 & 2.5 \\
\hline Vomiting & 0.0 & 0.0 & 0.0 & 14.0 & 12.0 & 16.0 & 15.6 & 13.4 & 17.9 \\
\hline \multicolumn{10}{|c|}{ Adverse events grade $\geq 3$} \\
\hline Anemia & 1.0 & 0.0 & 4.0 & 0.0 & 0.0 & 2.0 & 0.0 & 0.0 & 0.0 \\
\hline Asthenia (fatigue) & 1.0 & 0.0 & 14.0 & 1.0 & 0.0 & 4.0 & 0.9 & 0.0 & 1.7 \\
\hline Anorexia & 0.0 & 0.0 & 4.0 & 3.0 & 1.0 & 6.0 & 0.9 & 0.8 & 0.9 \\
\hline Arthralgia & 1.0 & 0.0 & 6.0 & 0.0 & 0.0 & 0.0 & 0.0 & 0.0 & 0.0 \\
\hline Diarrhea & 3.0 & 1.0 & 7.0 & 9.0 & 4.0 & 18.0 & 3.7 & 0.8 & 6.6 \\
\hline Rash & 6.0 & 2.0 & 19.0 & 15.0 & 12.0 & 19.0 & 0.4 & 0.0 & 0.8 \\
\hline Stomatitis/mucositis & 1.0 & 0.0 & 7.0 & 7.0 & 5.0 & 10.0 & 0.2 & 0.0 & 0.4 \\
\hline Constipation & 0.0 & 0.0 & 4.0 & 0.0 & 0.0 & 2.0 & 0.2 & 0.0 & 0.4 \\
\hline Infection & 1.0 & 0.0 & 7.0 & 0.0 & 0.0 & 0.0 & 3.9 & 2.1 & 5.7 \\
\hline Leukopenia & 0.0 & 0.0 & 0.0 & 0.0 & 0.0 & 2.0 & 0.0 & 0.0 & 0.0 \\
\hline Nausea & 0.0 & 0.0 & 0.0 & 1.0 & 0.0 & 3.0 & 0.2 & 0.0 & 0.0 \\
\hline Neurotoxicity & 1.0 & 0.0 & 6.0 & 0.0 & 0.0 & 0.0 & 0.0 & 0.0 & 0.0 \\
\hline Neutropenia & 0.0 & 0.0 & 2.0 & 0.0 & 0.0 & 2.0 & 0.6 & 0.4 & 0.8 \\
\hline Pruritus & 0.0 & 0.0 & 0.0 & 0.0 & 0.0 & 2.0 & 0.0 & 0.0 & 0.0 \\
\hline $\begin{array}{l}\text { Cheilitis (lips } \\
\text { inflammation) }\end{array}$ & 0.0 & 0.0 & 0.0 & 0.0 & 0.0 & 2.0 & 0.0 & 0.0 & 0.0 \\
\hline Thrombocytopenia & 0.0 & 0.0 & 2.0 & 0.0 & 0.0 & 0.0 & 0.0 & 0.0 & 0.0 \\
\hline Vomiting & 0.0 & 0.0 & 0.0 & 3.0 & 1.0 & 6.0 & 2.8 & 0.8 & 4.8 \\
\hline
\end{tabular}

Abbreviations: $\mathrm{Cl}$, confidence interval; LL, lower limit; UL, upper limit.

is the same (€68.18, ex-factory price) ${ }^{29}$ consequently, only costs associated with management of AEs were considered. AEs with irrelevant direct health care costs for the NHS (alopecia, ALT enzyme elevation, epistaxis, paronychia, and xerosis) were not taken into account.

Resource utilization and the unit costs employed in the study were obtained from different Spanish sources ${ }^{30-32}$ and were updated and clinically validated in 2015 by a Spanish panel of clinical experts composed of three oncologists (DI, JDC, and OJ) who are also co-authors of this study (Table 2). Spanish studies from which the cost of AE was obtained are described. Most of the unit costs of outpatient and in-hospital management of the AE were obtained from the study by Isla et al. ${ }^{30}$ In this study, a two-round Delphi consensus panel of clinical experts was carried out to describe local clinical patterns based on treatment algorithms from SEOM (Spanish Society of Medical Oncology) and ASCO (American Society of Clinical Oncology) treatment guidelines. The panel consisted of 19 oncologists and one hospital pharmacist, who were asked during the first round to define therapeutic pathways for NSCLC by the patients' performance status, age, and histology; to quantify the use of resources associated with the preparation and administration of anticancer pharmacotherapy; management of AEs associated with 





anticancer pharmacotherapy; and best supportive care (BSC). The second round was used to try to reduce the variability of responses in some questions and to further describe differences between intravenous and oral therapy ${ }^{30}$ (Table 2). The cost of AE not analyzed in Isla et $\mathrm{al}^{30}$ study was obtained from two other sources: one study of the treatment of patients with recurrent epithelial ovarian cancer, in which estimation of resources used in managing AE was made through an expert panel (stomatitis/mucositis, cheilitis); ${ }^{32}$ the second study was performed to estimate the management of nucleoside analog reverse transcriptase inhibitors-related toxicities (arthralgia, leukopenia, and neurotoxicity) ${ }^{31}$ (Table 2). It was assumed that the management of $\mathrm{AE}$ is similar in cancer patients and in patients with HIV.

All costs and prices used in the model were updated to the year 2015 .

\section{Monte Carlo simulation}

In the actual clinical practice, the clinical course may differ greatly among the patients of a NSCLC cohort. Similarly, the data referred to the variables of the model (AE rates and the costs of managing such events) can generate uncertainty as to their accuracy, since they come from different studies and sources that need to be contrasted. In this regard, the aforementioned panel of experts had already validated the previously published Spanish data on the use of resources in treating AEs among patients with NSCLC. ${ }^{30-32}$ In addition, a probabilistic analysis was made in the form of a second-order
Monte Carlo simulation to explore the effect of the individual variability of the patients and the uncertainty of the variables of the model ${ }^{33}$ in a hypothetical cohort of 1,000 patients treated with erlotinib or afatinib. We simulated the evolution of a hypothetical cohort in the clinical practice, obtaining mean cost differences with their corresponding 95\% confidence intervals (95\% CIs). We assumed that the rates and costs of the AEs would follow a beta and gamma distribution, respectively. ${ }^{34}$

\section{Presentation of results}

The unit costs of each AE were displayed first. This was followed by the mean cost of the AEs per patient according to severity (grades $\leq 2$ and $\geq 3$; with the corresponding $95 \%$ $\mathrm{CI})$ and the mean pooled cost $(95 \% \mathrm{CI})$ of the global AEs.

\section{Results}

The calculated mean, minimum, and maximum costs of each $\mathrm{AE}$ (grades $\leq 2$ and $\geq 3$ ) associated with erlotinib and afatinib are reported in Table 3 .

The total cost of the AEs per patient treated with erlotinib and afatinib was $€ 657.44$ and $€ 1,272.15$, respectively (Table 4).

With erlotinib, the cost of the AEs grades $\leq 2$ and $\geq 3$ was $€ 550.86$ and $€ 106.58$, respectively, while the cost with afatinib was $€ 980.63$ and $€ 291.52$, respectively (Table 4 ).

The reduction in the number of AEs with erlotinib could result in a cost saving for the NHS of $€ 614.71$ (95\% CI $€ 342.57-881.29$ ) per patient (Table 4).

Table 3 Cost of management of the adverse event $(A E)$ grades $\leq 2$ and $\geq 3$

\begin{tabular}{|c|c|c|c|c|c|c|}
\hline \multirow[t]{2}{*}{ Adverse event } & \multicolumn{3}{|c|}{ Cost management AE grade $\leq 2$} & \multicolumn{3}{|c|}{ Cost management $A E$ grade $\geq 3$} \\
\hline & Mean $(€)$ & Minimum (€) & Maximum (€) & Mean $(€)$ & Minimum (€) & Maximum (€) \\
\hline Anemia & 362.46 & 289.97 & 434.96 & 490.06 & 392.04 & 588.07 \\
\hline Asthenia/fatigue & 1.21 & 0.00 & 1.45 & 171.34 & 0.00 & 342.69 \\
\hline Anorexia & 10.05 & 0.00 & 16.17 & 10.05 & 0.00 & 32.33 \\
\hline Arthralgia & 16.80 & 13.44 & 20.16 & 261.09 & 16.80 & 505.39 \\
\hline Diarrhea & 919.29 & 551.57 & $1,103.15$ & $\mathrm{I}, 5 \mathrm{I} 6.83$ & 995.51 & $1,820.19$ \\
\hline Rash & 2.06 & 1.65 & 2.48 & 2.06 & 1.65 & 2.48 \\
\hline Stomatitis/mucositis & 137.47 & 109.98 & 164.97 & $1,321.35$ & 931.64 & $1,711.06$ \\
\hline Constipation & 0.77 & 0.61 & 0.92 & 0.77 & 0.61 & 0.92 \\
\hline Infection & 612.45 & 489.96 & 734.94 & I,789.98 & I,43I.98 & $2,147.97$ \\
\hline Leukopenia & 671.33 & 537.06 & 805.60 & I,566.40 & 671.33 & $2,46 \mid .47$ \\
\hline Nausea & 212.80 & 170.24 & 407.21 & 485.31 & 388.25 & 582.38 \\
\hline Neurotoxicity & 462.54 & 370.03 & 555.05 & I,171.35 & 462.54 & $1,880.16$ \\
\hline Neutropenia & 479.55 & 383.64 & 575.46 & $|, 86| .8 \mid$ & $\mathrm{I}, 489.45$ & $2,234.17$ \\
\hline Paronychia & 0.00 & 0.00 & 0.00 & 0.00 & 0.00 & 0.00 \\
\hline Pruritus & 0.00 & 0.00 & 0.00 & 9.71 & 7.76 & 11.65 \\
\hline Cheilitis & 0.00 & 0.00 & 0.00 & 0.00 & 0.00 & 0.00 \\
\hline Thrombocytopenia & 249.94 & 199.95 & 299.93 & 907.04 & 725.63 & $\mathrm{I}, 088.45$ \\
\hline Vomiting & 212,80 & 170,24 & 407,21 & I,402.30 & $1,121.84$ & $\mathrm{I}, 682.77$ \\
\hline
\end{tabular}

Notes: The costs include both the outpatient and in-hospital management of the AEs. Calculation was made from the works of Isla et al, ${ }^{30}$ Llibre et al, ${ }^{31}$ and Ojeda et al, ${ }^{32}$ with validation by the panel of experts. 
Table 4 Cost per patient of management of the adverse events (AEs) according to the Monte Carlo simulation

\begin{tabular}{|c|c|c|c|}
\hline AE severity & Erlotinib & Afatinib & Difference $(95 \% \mathrm{CI}) *$ \\
\hline$A E$ grade $\leq 2$ & $€ 550.86$ & $€ 980.63$ & $\begin{array}{l}€-429.76 \\
(€-292.48 \text { to }-536.40)\end{array}$ \\
\hline$A E$ grade $\geq 3$ & $€ 106.58$ & $€ 291.52$ & $\begin{array}{l}€-184.95 \\
(€-50.08 \text { to }-344.89)\end{array}$ \\
\hline All AEs & $€ 657.44$ & $€ 1,272.15$ & $\begin{array}{l}€-6|4.7| \\
(€-342.57 \text { to }-881.29)\end{array}$ \\
\hline
\end{tabular}

Note: *The negative values indicate savings with erlotinib versus afatinib.

Abbreviation: $\mathrm{Cl}$, confidence interval.

On examining the costs of managing each AE, diarrhea was found to make the greatest contribution to total management cost, representing $61.3 \%$ and $76.0 \%$ of the total cost for erlotinib and afatinib, respectively, followed by infections $(17.6 \%$ for erlotinib) and stomatitis/mucositis (15.0\% for afatinib).

According to the sub-analysis performed with $\mathrm{AE}$ rates described for afatinib in the ClinicalTrials database, the saving per patient for the NHS would be $€ 701.51$ (95\% CI $€ 409.27-867.22$ ).

\section{Discussion}

EGFR-TKIs are incontestable standard treatments for NSCLC patients with EGFR mutations. ${ }^{35}$ While most published meta-analyses suggest that there are no differences in terms of efficacy among EGFR-TKIs, ${ }^{14-17}$ the last meta-analysis released suggests that there is no difference between erlotinib and afatinib but there is difference between these two and gefitinib. ${ }^{18}$ Due to the lack of head-to-head studies and considering that erlotinib and afatinib have no efficacy differences coming from indirect comparisons, we aimed to compare both drugs in terms of direct costs. Since pharmacological costs can be considered similar in Spain, only costs associated with AEs were considered in the analysis.

Our economic evaluation had some weaknesses and strengths. First, we should take into account that we have used a theoretical model, which by definition constitutes a simplified simulation of reality. There are no head-to-head trials comparing erlotinib versus afatinib in EGFR-positive NSCLC, but this weakness could be solved by the use of a thorough network meta-analysis. ${ }^{14}$ However, in this regard, the methodological problems associated with the meta-analysis of indirect comparisons must be considered. ${ }^{36}$ On the other hand, this meta-analysis included trials which were based on nonpragmatic designs. Consequently, their results must be regarded as estimates referred to a standardized patient.

Data on resource utilization in the management of AEs could not be collected from real patients, which are always the preferable option. Such information was estimated considering a specific published study on patients with NSCLC, which included a panel of 19 Spanish oncologists, ${ }^{30}$ and it was updated and validated in 2015 by another panel of clinical experts composed of three oncologists (DI, JDC, and OJ) who are also co-authors of this study.

The costs of management of AEs used in our modeled study mainly come also from this Spanish publication. ${ }^{30}$ However, in some cases we had to resort to another two Spanish studies not specific of this disease, ${ }^{31,32}$ and we assumed that management of the AEs does not vary significantly in patients with different diseases. ${ }^{30,37}$ However, can be considered a weakness of the model, the need to assume the management of AE is similar in cancer patients and in patients with HIV.

Regarding the strengths of the study, we must emphasize that the reliability of the results of the economic analysis was confirmed by means of a Monte Carlo simulation. ${ }^{33}$ This mathematical method allows us to simulate the effect of simultaneous and random changes referred to different parameters (in our case, the frequencies and costs of AEs), thereby attempting to imitate the real-life clinical evolution of the patients. This method is widely accepted and recommended by institutions such as, for example, the "National Institute for Health and Care Excellence" of the United Kingdom. ${ }^{38}$ The reliability of the results obtained was confirmed in this probabilistic analysis, revealing savings per patient, with a $95 \%$ CI between $€ 342.57$ and $€ 881.29$. The orientation of the results (savings with erlotinib versus afatinib) was likewise confirmed on incorporating the afatinib AE rates recently described in the ClinicalTrials database to the calculations made.

According to the results of this study, first-line treatment of EGFR mutation-positive advanced NSCLC patients with erlotinib could reduce the health care costs for the NHS, due to a decrease in the AE rate compared with afatinib. However, this result should be confirmed in an ad hoc study in clinical practice. In long-term treatments, the avoidance of complications and the lowering of costs associated with the management of AEs are relevant factors that contribute to the sustainability of the health care system.

\section{Acknowledgments}

This study was sponsored by Roche Farma, S.A., Madrid, Spain. This study has been carried out with an unrestricted research grant from Roche Farma, S.A.

\section{Disclosure}

JO and RG are employees of Roche Farma, S.A., Madrid, Spain. CR-T and DR-R have received honoraria from Roche 
Farma, S.A., Madrid, Spain, in connection with the development of this manuscript. The authors report no other conflicts of interest in this work.

\section{References}

1. National Epidemiology Center. Centro Nacional de Epidemiología. Mortalidad por cáncer y otras causas en España; 2013 [Mortality from cancer and other causes in Spain; 2013]. Available from: http:// www.isciii.es/ISCIII/es/contenidos/fd-servicios-cientifico-tecnicos/ fd-vigilancias-alertas/fd-epidemiologia-ambiental-y-cancer/mortalidadcancer-en-espana.shtml. Accessed March 7, 2016. Spanish.

2. Ferlay J, Bray F, Steliarova-Foucher E, Forman D. Cancer incidence in five continents, CI5plus: IARC cancerbase No. 9. Lyon, France: International Agency for Research on Cancer; 2014. Available from: http://ci5.iarc.fr. Accessed March 15, 2016.

3. Sánchez de Cos Escuín J, Miravet Sorribes L, Abal Arca J, et al. Estudio multicéntrico epidemiológico-clínico de cáncer de pulmón en España (estudio EpiCliCP-2003) [The EpicliCP-2003 study: a multicenter epidemiological and clinical study of lung cancer in Spain]. Arch Bronconeumol. 2006;42(9):446-452. Spanish.

4. Miravet L, Paradís A, Peláez S, Arnal M, Cabadés F. Evolución del carcinoma broncopulmonar en el norte de la provincia de Castellón, 1993-2002 [Evolution of lung cancer in the North of the province of Castellón, Spain, 1993-2002]. Arch Bronconeumol. 2004;40(12):553-557. Spanish.

5. Montero C, Rosales M, Otero I, et al. Cáncer de pulmón en el área sanitaria de A Coruña: incidencia, abordaje clínico y supervivencia [Lung cancer in the health care area of A Coruña (Spain): incidence, clinical approach and survival]. Arch Bronconeumol. 2003;39(5):209-216. Spanish.

6. Rosell R, Moran T, Queralt C, et al; Spanish Lung Cancer Group. Screening for epidermal growth factor receptor mutations in lung cancer. N Engl J Med. 2009;361(10):958-967.

7. Mitsudomi T, Kosaka T, Yatabe Y. Biological and clinical implications of EGFR mutations in lung cancer. Int J Clin Oncol. 2006;11(3):190-198.

8. Tarceva. Summary of product characteristics. European Medicines Agency. Available from: http://www.ema.europa.eu/ema/ index.jsp?curl=pages $/$ medicines $/$ human $/$ medicines $/ 000618 /$ human med_001077.jsp\&mid=WC0b01ac058001d124. Accessed March 5, 2016.

9. Iressa. Summary of Product Characteristics. European Medicines Agency. Available from: http://www.ema.europa.eu/docs/en_GB/ document_library/EPAR_-_Product_Information/human/001016/ WC500036358.pdf. Accessed March 5, 2016.

10. Giotrif. Summary of Product Characteristics. European Medicines Agency. Available from: http://www.ema.europa.eu/docs/en_GB/ document_library/EPAR_-_Product_Information/human/002280/ WC500152392.pdf. Accessed March 5, 2016.

11. Suda K, Mizuuchi H, Maehara Y, Mitsudomi T. Acquired resistance mechanisms to tyrosine kinase inhibitors in lung cancer with activating epidermal growth factor receptor mutation - diversity, ductility, and destiny. Cancer Metastasis Rev. 2012;31(3-4):807-814.

12. Hynes NE, Lane HA. ERBB receptors and cancer: the complexity of targeted inhibitors. Nat Rev Cancer. 2005;5(5):341-354.

13. Yang JC, Wu YL, Schuler M, et al. Afatinib versus cisplatin-based chemotherapy for EGFR mutation-positive lung adenocarcinoma (LUXLung 3 and LUX-Lung 6): analysis of overall survival data from two randomised, phase 3 trials. Lancet Oncol. 2015;16(2):141-151.

14. Haaland B, Tan PS, de Castro G, Jr, Lopes G. Meta-analysis of first-line therapies in advanced non-small-cell lung cancer harboring EGFRactivating mutations. J Thorac Oncol. 2014;9(6):805-811.

15. Haspinger ER, Agustoni F, Torri V, et al. Is there evidence for different effects among EGFR-TKIs? Systematic review and meta-analysis of EGFR tyrosine kinase inhibitors (TKIs) versus chemotherapy as firstline treatment for patients harboring EGFR mutations. Crit Rev Oncol Hematol. 2015;94(2):213-227.
16. Liang $\mathrm{W}, \mathrm{Wu} \mathrm{X}$, Fang $\mathrm{W}$, et al. Network meta-analysis of erlotinib, gefitinib, afatinib and icotinib in patients with advanced non-smallcell lung cancer harboring EGFR mutations. PLoS One. 2014; 9(2):e85245.

17. Popat S, Mok T, Yang JC, et al. Afatinib in the treatment of EGFR mutation-positive NSCLC - a network meta-analysis. Lung Cancer. 2014; 85(2):230-238.

18. Zhang Y, Sheng J, Yang Y, et al. Optimized selection of three major EGFR-TKIs in advanced EGFR-positive non-small cell lung cancer: a network metaanalysis. Oncotarget. 2016;7(15):20093-20108.

19. Park K, Tan EH, O`Byrne K, et al. Afatinib versus gefitinib as first-line treatment of patients with EGFR mutation-positive non-small-cell lung cancer (LUX-Lung 7): a phase 2B, open-label, randomised controlled trial. Lancet Oncol. 2016;17(5):577-589.

20. Yang J, Zhou Q, Yan HH, et al. A randomized controlled trial of erlotinib versus gefitinib in advanced non-small-cell lung cancer harboring EGFR mutations (CTONG0901). In: 16th World Conference on Lung Cancer; September 6-9, 2015; Denver, CO, USA. Abstract 16.13.

21. Zhou C, Wu YL, Chen G, et al. Erlotinib versus chemotherapy as firstline treatment for patients with advanced EGFR mutation-positive non-small-cell lung cancer (OPTIMAL, CTONG-0802): a multicentre, open-label, randomised, phase 3 study. Lancet Oncol. 2011;12(8): $735-742$.

22. Zhou C, Wu YL, Liu X, et al. Overall survival (OS) results from OPTIMAL (CTONG0802), a phase III trial of erlotinib (E) versus carboplatin plus gemcitabine (GC) as first-line treatment for Chinese patients with EGFR mutation-positive advanced non-small cell lung cancer (NSCLC). J Clin Oncol. 2012;30(Suppl). Abstract 7520.

23. Sequist LV, Yang JC, Yamamoto N, et al. Phase III study of afatinib or cisplatin plus pemetrexed in patients with metastatic lung adenocarcinoma with EGFR mutations. J Clin Oncol. 2013;31(27): 3327-3334.

24. Wu YL, Zhou C, Hu CP, et al. LUX-Lung 6: a randomized, open label, phase III study of afatinib (A) versus gemcitabine/cisplatin (GC) as first-line treatment for Asian patients (pts) with EGFR mutation positive (EGFR M+) advanced adenocarcinoma of the lung. J Clin Oncol. 2013;31(Suppl). Abstract 8016.

25. Rosell R, Carcereny E, Gervais R, et al. Erlotinib versus standard chemotherapy as first-line treatment for European patients with advanced EGFR mutation-positive non-small-cell lung cancer (EURTAC): a multicentre, open-label, randomised phase 3 trial. Lancet Oncol. 2012;13(3):239-246.

26. Wu YL, Zhou C, Hu CP, et al. Afatinib versus cisplatin plus gemcitabine for first-line treatment of Asian patients with advanced non-small-cell lung cancer harbouring EGFR mutations (LUX-Lung 6): an open-label, randomised phase 3 trial. Lancet Oncol. 2014;15(2):213-222.

27. Clinical Trials, 2016a. BIBW 2992 (afatinib) versus chemotherapy as first line treatment in NSCLC with EGFR mutation. Available from: https://clinicaltrials.gov/ct2/show/results/NCT00949650. Accessed April 5, 2016.

28. Clinical Trials, 2016b. BIBW 2992 (Afatinib) vs gemcitabine-cisplatin in 1st line Non-small Cell Lung Cancer (NSCLC). Available from: https:// clinicaltrials.gov/ct2/show/results/NCT01121393?sect=X3n0156\#evnt. Accessed April 5, 2016.

29. BotPlus 2.0. General Council of Official Colleges of Pharmacists. Available from: https://botplusweb.portalfarma.com/. Accessed April 20, 2016. Spanish.

30. Isla D, González-Rojas N, Nieves D, Brosa M, Finnern HW. Treatment patterns, use of resources, and costs of advanced non-small-cell lung cancer patients in Spain: results from a Delphi panel. Clin Transl Oncol. 2011;13(7):460-471.

31. Llibre-Codina JM, Casado-Gómez MA, Sánchez-de la Rosa R, et al. Coste de la toxicidad asociada a los análogos de nucleósidos inhibidores de la transcriptasa inversa en pacientes con infección por el VIH-1 [Cost of nucleoside analogue reverse transcriptase inhibitor-related toxicity in HIV-1-infected patients]. Enferm Infecc Microbiol Clin. 2007;25(2):98-107. Spanish. 
32. Ojeda B, de Sande LM, Casado A, Merino P, Casado MA. Cost-minimisation analysis of pegylated liposomal doxorubicin hydrochloride versus topotecan in the treatment of patients with recurrent epithelial ovarian cancer in Spain. Br J Cancer. 2003;89(6):1002-1007.

33. Rubio-Terrés C, Cobo E, Sacristán JA, Prieto L, del Llano J, Badía X; Grupo ECOMED. [Analysis of uncertainty in the economic assessment of health interventions]. Med Clin (Barc). 2004;122(17):668-674. Spanish.

34. Briggs A, Claxton K, Sculpher M. Decision Modelling for Health Economic Evaluation. Oxford, UK: Oxford University Press; 2006.

35. García-Campelo R, Bernabé R, et al. SEOM clinical guidelines for the treatment of non-small cell lung cancer (NSCLC) 2015. Clin Transl Oncol. 2015;17(12):1020-1029.
36. Jansen JP, Trikalinos T, Cappelleri JC, Daw J, Andes S, Eldessouki R, Salanti G. Indirect treatment comparison/network meta-analysis study questionnaire to assess relevance and credibility to inform health care decision making: an ISPOR-AMCP-NPC Good Practice Task Force report. Value Health. 2014;17(2):157-173.

37. Nysoe TE, Paauw DS. Symptom management. In: Bartlett JG, Cheever LW, Johnson MP, Paauw DS, Editors. A Guide to Primary Care of People with HIV/AIDS. Rockville, MA: U.S. Department of Health and Human Services; 2004:55.

38. National Institute for Health and Care Excellence. Guide to the Methods of Technology Appraisal; 2013. Available from: https://www.nice.org. $\mathrm{uk} /$ article/pmg9/resources/non-guidance-guide-to-the-methods-oftechnology-appraisal-2013-pdf. Accessed April 19, 2016.
ClinicoEconomics and Outcomes Research

\section{Publish your work in this journal}

ClinicoEconomics and Outcomes Research is an international, peerreviewed open-access journal focusing on health technology assessment, pharmacoeconomics and outcomes research in the areas of diagnosis, medical devices, and clinical, surgical and pharmacological intervention. The economic impact of health policy and health systems
Submit your manuscript here: https://www.dovepress.com/clinicoeconomics-and-outcomes-research-jourat

organization also constitute important areas of coverage. The manuscript management system is completely online and includes a very quick and fair peer-review system, which is all easy to use. Visit http://www.dovepress.com/testimonials.php to read real quotes from published authors. 